\title{
食道再建を目的とした非定型的遊離小腸移植術
}

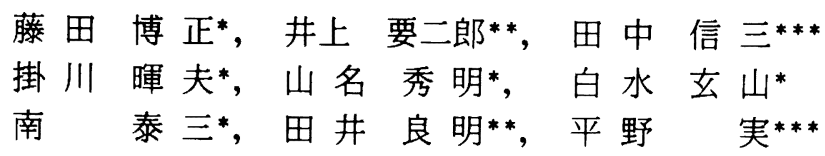

\section{Atypical Free Gut Transfer for Esophageal Reconstruction}

\author{
Hiromasa Fujita, M.D., ${ }^{*}$ Yojiro Inoue, M.D., ${ }^{* *}$ \\ Shinzo Tanaka, M.D.,"** Teruo Kakegawa, M.D., ${ }^{*}$ \\ Hideaki Yamana, M.D.," Genzan Shirouzu, M.D.,* \\ Taizo Minami, M.D.," Yoshiaki Tai, M.D., ${ }^{* *}$ \\ and Minoru Hirano, M.D.*** \\ Departments of *Surgery I, **Plastic Surgery, and ***Otorhinolaryngology, \\ Kurume University School of Medicine, Kurume
}

\begin{abstract}
An esophageal reconstruction using a free bowel graft following pharyngolaryngoeso. phagectomy for a carcinoma involving the pharynx or cervical esophagus can be termed "typical" free gut transfer, while other types of reconstruction using a free bowel graft can be termed "atypical." During the period from 1988 to 1989, we have experienced 23 cases of free gut transfer in our hospital. Twelve cases of these underwent typical operation. An atypical operation was performed in 11 cases involving 4 cases of a carcinoma of the hypopharynx or cervical esophagus, 3 cases of a recurrence following esophagectomy for a carcinoma in the thoracic esophagus, one case of a carcinoma in the esophagus at the cervicothoracic junction, one case with cervical esophagostomy following esophagectomy for a carcinoma in the thoracic esophagus, one case of recurrence following chemotherapy for a breast carcinoma, and one case of pharyngoesophageal corrosive stricture. From our experience of atypical free gut transfer, we conclude that the free gut transfer is useful for the reconstruction of various types of a pharyngoesophageal defect. Also we conclude that the cervical transverse artery and the external jugular vein as the recipient vessels in the neck are most convenient, and the thoracoacromial artery and the cephalic vein are most convenient in the anterior chest wall. Important postoperative complications involved aspiration pneumonia in cases preserving the larynx, dysphagia in cases with free graft of the long intestine, and graft failure due to a vascular obstruction. However, these complications could be avoided with improvement in the operative indications, the procedures and techniques employed.
\end{abstract}

Key words : free jejunal graft, free gut transfer, microvascular surgery, esophageal reconstruction

\footnotetext{
*久留米大学医学部第 1 外科学教室, **同・形成外科学教室, ***同・耳鼻咽喉科学教室 別刷請求： $=830$ 福岡県久留米市旭町 67 久留米大学医学部第 1 外科学教室 藤田博正 投稿受付：1990年 6 月 8 日
} 


\section{I .はじめに}

1957年 Seidenbergにより, 頸部食道癌の再 発のため咽頭喉頭頸部食道摘出術が行われた症 例に対し，初めて遊離空腸移值術が行われた1)。 その後, 中山ら ${ }^{2)}$, 中村ら ${ }^{3)}$ の血管吻合手技上の 改良にもかかわらず，遊離腸管移植術は一般化 されるに至らなかった。1970年代の後半に入り, 顕微鏡下の血管吻合術 microvascular surgery が導入されるに及んで，この手術は高い成功率 を得て急速に広まった ${ }^{4,5)}$ 。現在では, 下咽頭頸 部食道癌切除後の再建法において, 定型的手術 (咽頭と胸部食道の間に遊離小腸を間置したも の）として確立されている。

一方, この定型的手術とは異なる遊離腸管移 植術としての非定型的手術も多く行われている が6 9), これにはまだ確立された術式がなく,い くつかの問題点も残されている。本論文では私 たちが非定型的遊離腸管移植術と称している 種々の術式を紹介するとともに，その治療成績 について検討する。

\section{II. 対 象}

1988 年から 1989 年の 2 年間に, 久留米大学第 1 外科および耳鼻咽喉科において施行された遊 離小腸移植術23例の原疾患と術式を表 1 に示 す。私たちは表の点線より上段，すなわち下咽 頭頸部食道癌に対する咽頭喉頭頸部食道摘出 ・ 咽頭食道間遊離小腸間置術（12例）を定型的手 術とし，点線より下段にかかげた手術を非定型 的手術として分類している。この報告では非定 型的手術が行われた11例を対象とした。

対象症例の概要を述べる。性別では男 7 例, 女 4 例, 年齢は $30 \sim 66$ 歳で平均 55.4 歳であった。 原疾患は表 1 に示すように, 下咽頭頸部食道癌 4 例, 頸胸境界部食道癌 1 例, 胸部食道癌再発 3 例, 胸部食道癌術後 - 頸部食道瘦 1 例, 乳癌 化療後再発 1 例, 瘢痕性咽頭頸部食道狭窄 1 例 であった。再建法として, 狭窄部切除後または 食道欠損部に小腸を間置した症例 9 例, 狭窄部 を残し bypass した症例 2 例であった。再建に 使用された遊離腸管は空腸が 10 例, 回腸が 1 例

表 1 遊離小腸移植術

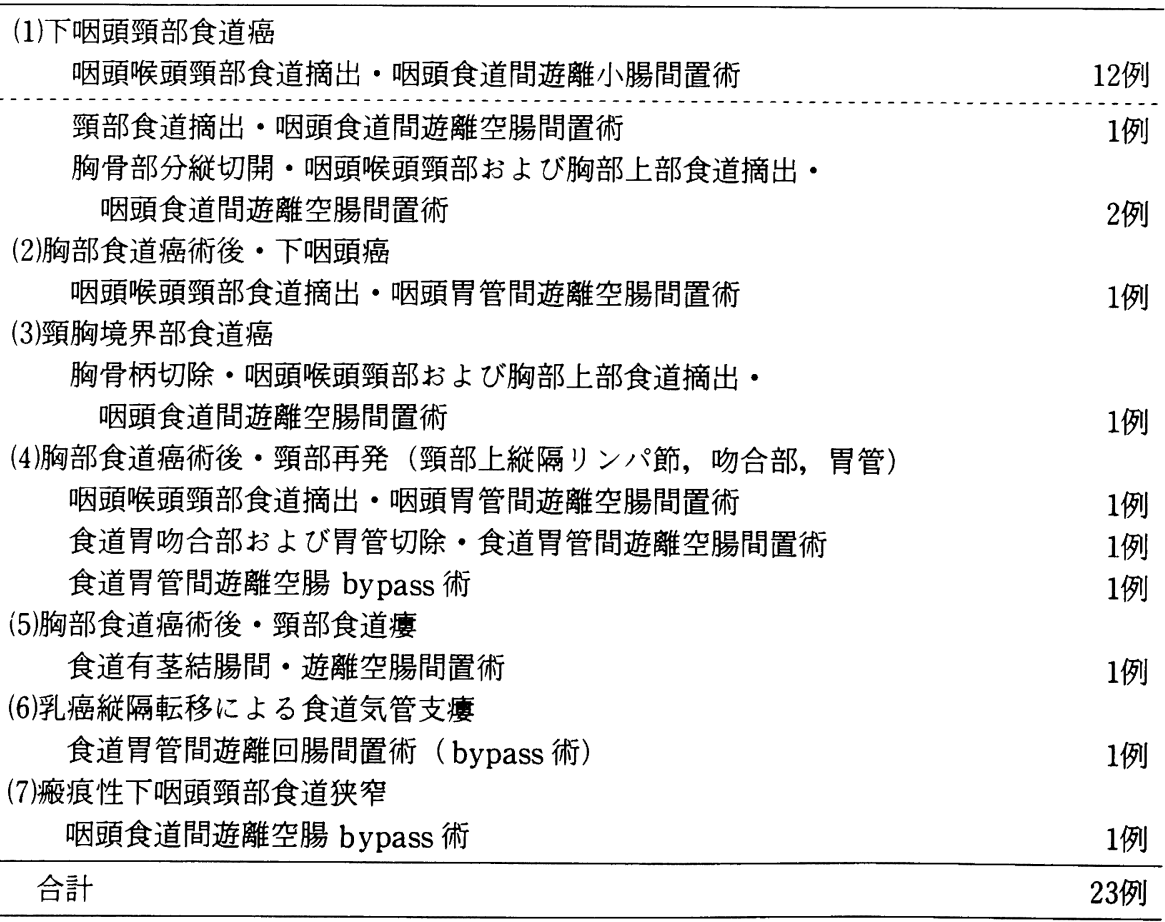


であった。口側腸管は咽頭が 8 例, 頸部食道が 3 例, 肛門側腸管は食道が 5 例，胃管が 5 例, 有茎結腸が 1 例であった。血管吻合に用いられ た recipient 動脈は頸横動脈が 7 例, 胸肩峰動 脈が 3 例, 舌動脈が 1 例で, recipient 静脈は外 頸静脈が 7 例, 撓側皮静脈が 2 例, 内頸静脈が 1 例, 頸横静脈が 1 例であった。

\section{III. 症例}

症例 $1 ： 62$ 歳の女性。頸部食道癌で頸部食 道摘出後に咽頭食道接合部々形胸境界部食道の 間を $5 \mathrm{~cm}$ 長の遊離空間で再建した。血管吻合 には頸横動脈と外頸静脈を用いた(図 1)。さら に術後の誤嚥を防止するため喉頭挙上術も追加 した。

この症例は, 術後に両側反回神経麻痺をきた し，著しい誤曣のため経口摄取ができなかった ので, 5 力月後に喉頭摘出術を余儀なくされた。 その後の経過は順調である。

症例 2：57歳の女性。頸部食道癌で上縦隔 リンパ節転移を認めたため, 胸骨部分縦切開の 後, 咽頭喉頭頸部および胸部上部食道を摘出し, 咽頭と胸部食道の間を $10 \mathrm{~cm}$ 長の遊離空腸で再 建した。血行再建は頸横動脈と外頸静脈を用い た（図 2 ）。術後空腸食道吻合部（器械吻合）の

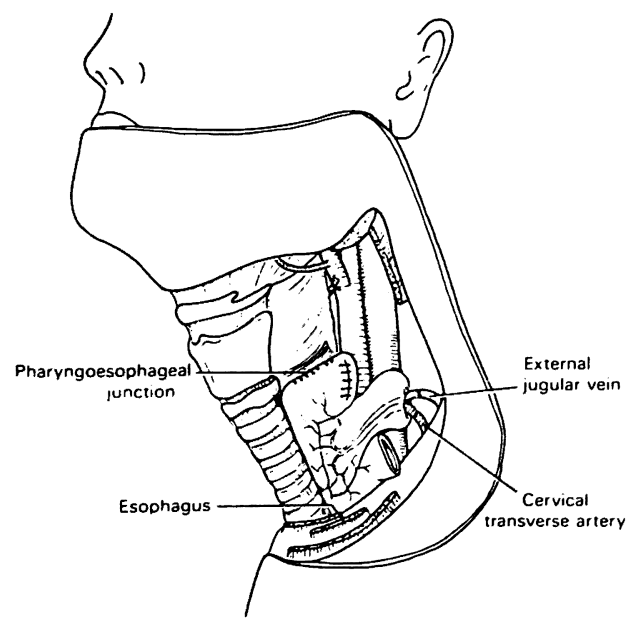

図 1 症例 1

頸部食道癌で頸部食道摘出後に, 咽頭食道接合部と 頸胸境界部食道間に遊離空腸を間置した。空腸上下 とも端側吻合とし，下端を空腸瘻とした。
狭窄をきたしたが，ブジーで容易に拡張され， 経過は順調である。

症例 $3 ： 53$ 歳の男性。胸部食道癌根治術後 6 年で下咽頭癌を発症した。咽頭喉頭頸部食道 を摘出し, 咽頭と胃管の間を遊離空腸で再建し

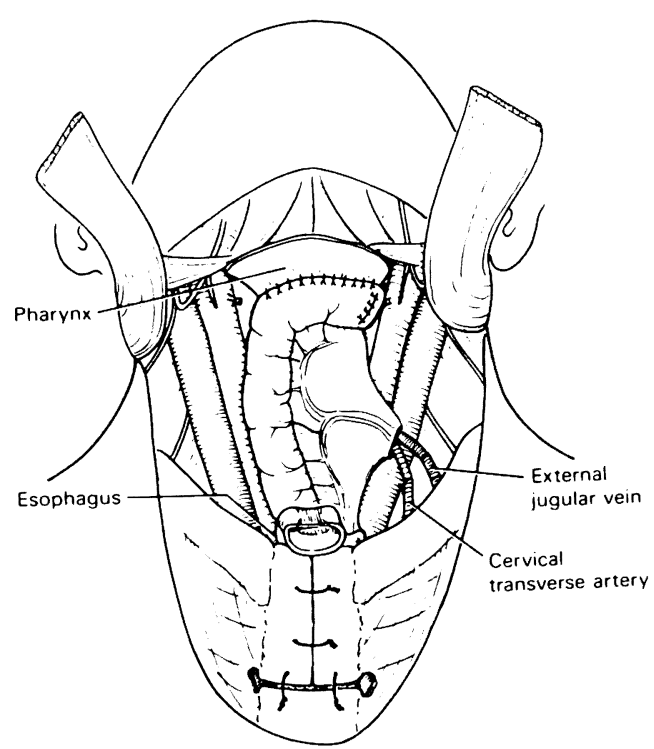

図 2 症例 2

頸部食道癌で胸骨部分緃切開にて, 咽頭喉頭頸部お よび胸部上部食道を摘出し, 咽頭と胸部食道間に遊 離空腸を間置した。空腸上下とも端側吻合とした。

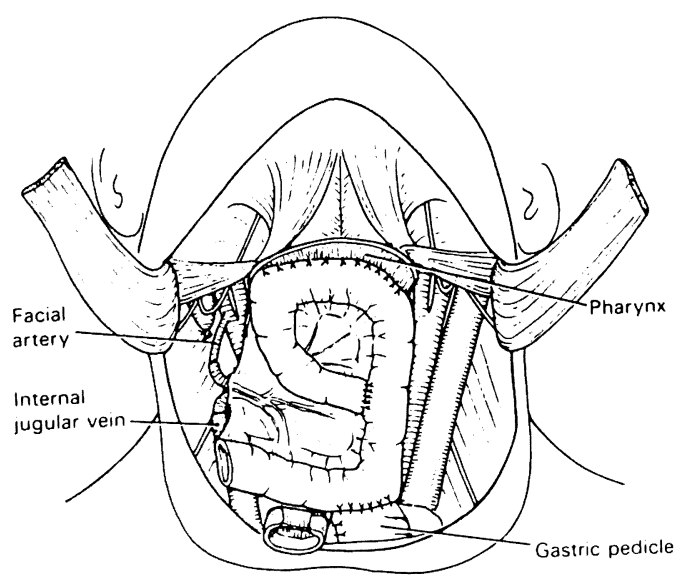

図 3 症例 3

胸部食道癌術後の下咽頭癌で, 咽頭喉頭頸部食道摘 出後に咽頭と胃管間に遊離空腸を間置した。P吻合 とし，下端を空腸癭とした。 
た。血管吻合には舌動脈と内頸静脈を用いた(図 3 )。移植空腸が $20 \mathrm{~cm}$ と長かったため, 術後 7.5 カ月にわたって通過障害を訴えたが，その後は 順調である。

症例 4：58歳の男性。頸胸境界部食道癌で 胸骨柄切除後に咽頭喉頭頸部および胸部上部食 道を摘出し，咽頭と胸部食道の間を $10 \mathrm{~cm}$ 長の 遊離空腸で再建した。血管吻合には頸横動脈と 外頸静脈を用いた（図 4 )。術後透視で，空腸食 道吻合部は大動脈弓部の高さにあった。なお, 縦隔気管瘻で問題となる気管の阻血性変化は, この症例ではみられず，順調に経過した。

症例 5 ：53歳の男性。胸部食道癌根治術後 1 年にて頸部食道再発(壁内転移)，および頸部 上縦隔のリンパ節再発をきたした。咽頭喉頭頸 部食道を摘出し，咽頭と胃管の間を $15 \mathrm{~cm}$ 長の 遊離空腸で再建した。血管吻合には頸横動脈と 外頸静脈を用いた(図 5 )。術後，移植空腸の壊 死をきたし， 5 病日目に切除し，咽頭瘻と胃瘻 を作製した。

その後, 癌遺残部に $60 \mathrm{~Gy}$ の照射を行い, 再度 再建の機会を待っていたが, 術後 7 力で左総 頸動脈気管瘦（癌遺残部）をきたし在院死亡と なった。

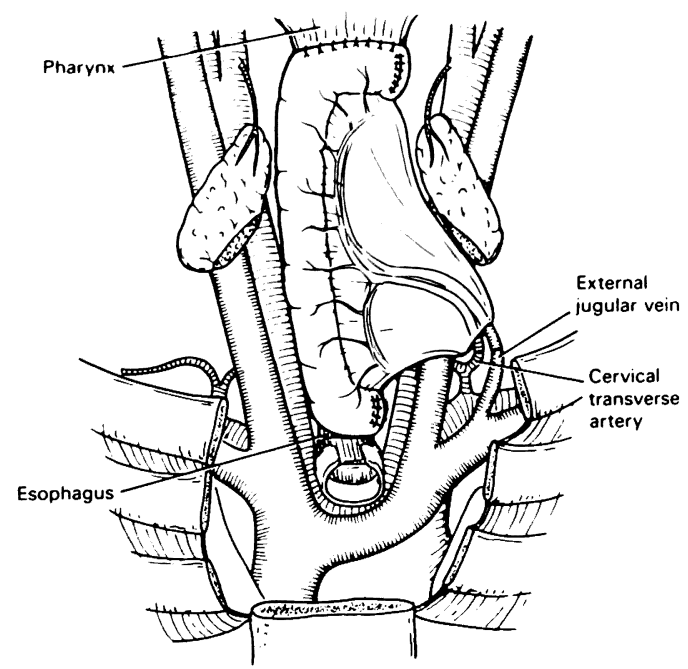

図4 症例 4

頸胸境界部食道癌で胸骨柄切除後, 咽頭喉頭頸部お よび胸部上部食道を摘出し, 咽頭と胸部食道間に遊 離空腸を間置した。空腸上下とも端側吻合とした。
症例 6：62歳の男性。胸部食道癌根治術後 1 年 7 カ月にて, 吻合部および胃壁内転移をき たした。食道胃吻合部ならびに胃管上半部を切

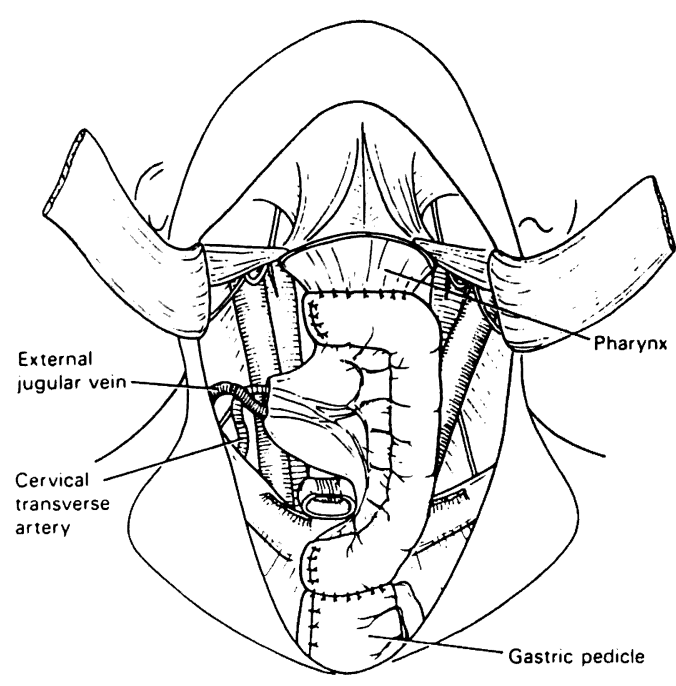

図 5 症例 5

胸部食道癌術後の頸部食道および頸部上縌隔りンパ 節再発に対し, 咽頭喉頭頸部食道を摘出し, 咽頭と 胃管間に遊離空腸を間置した。空腸上下とも端側吻 合とした。

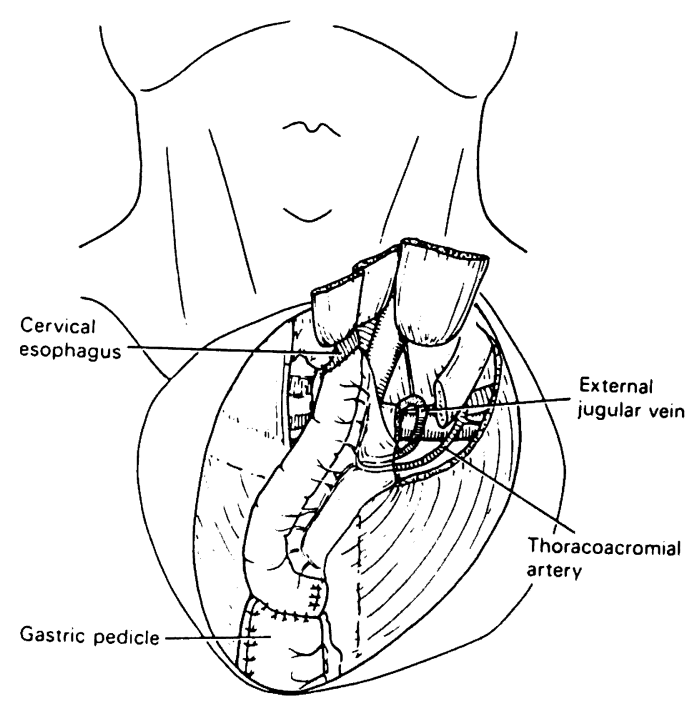

图 6 症例 6

胸部食道癌術後の吻合部および胃管内再発に対し， 食道胃吻合部と胃管上半部を摘出し，食道胃管間に 遊離空腸を間置した。空腸口側は端々吻合，肛門側 は端側吻合とした。 
除し, $15 \mathrm{~cm}$ 長の遊離空腸で再建した。吻合に用 いた血管は胸肩峰動脈と外頸静脈であった（図 $6) 。 こ の$ 症例では空腸胃吻合部は乳頭の高さに 達し, 遊離空腸によってほほ全長の胸壁前食道 再建が可能なことが示された。一方, 術後左反 回神経麻瘴をきたし，吻合部狭窄がなかったに もかかわらず，嚥下性肺炎を繰り返し，退院ま で3.5力月を要した。退院後 1.5 力月で肝転移の ため死亡した。

症例 7：66歳の男性。胸部食道癌根治術後 2 年で頸部上緃隔リンパ節再発を認めた。50 Gy の放射線治療を行ったところ，その 9 力月 後, 頸部食道から食道胃吻合部にかけて高度の 痏痕性狭窄をきたした。胸骨柄を切除し，咽頭 と胃管の間を $10 \mathrm{~cm}$ 長の遊離空腸で bypass し た。血管吻合には頸横動脈と外頸静脈を用いた (図 7 )。術後順調に経過して経口捸取を開始し, 気管再発部（空腸胃吻合部が含まれた）に追加 照射を行っていた。 $20 \mathrm{~Gy}$ 追加したところで空 腸胃吻合部の縫合不全をきたした。創部の改善 を待って, 大胸筋皮弁による㾇孔閉鎖術を行っ たが，気管再発と圜下性肺炎のため 6 力月後に 在院死亡となった。

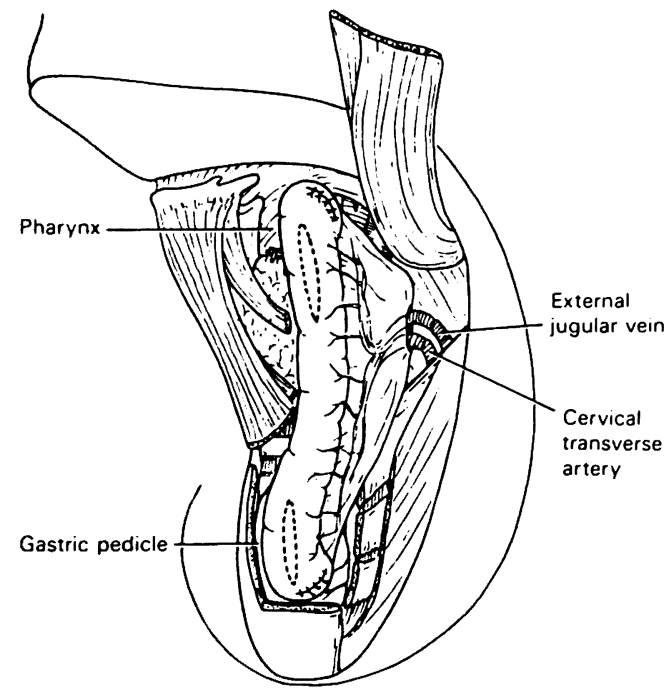

图7 症例 7

胸部食道癌術後の頸部上綐隔リンパ節再発に対する 放射線治療で, 食道胃管吻合部を中心に瘢痕性狭窄 をきたした。胸骨柄を切除し，咽頭と胃管間を遊離 空腸で bypassした。空腸上下とも側々吻合とした。
症例 8：54歳の男性。胸部食道癌根治術後 の頸部食道瘻と胸壁前結腸瘻に対し，二期的に 遊離空腸 $(10 \mathrm{~cm}$ 長) で再建した。血管吻合には 胸肩峰動脈と撓側皮静脈を用いた(図 8 )。術後 順調に経過し，1 1 月で退院した。この症例の 経験から大胸筋鎖骨付着部を切断することによ

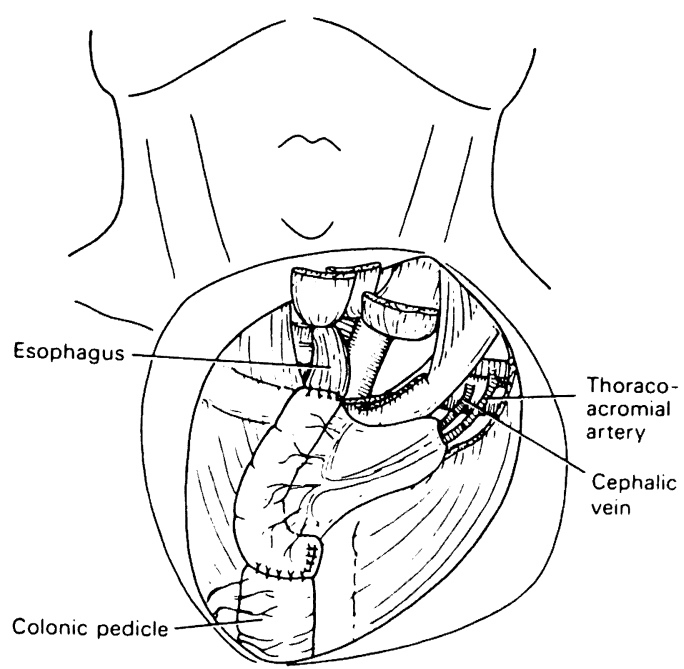

図 8 症例 8

胸部食道癌術後の頸部食道瘦と胸壁前結腸瘦に対 し, 食道結腸間に遊離空腸を間置した。空腸口側は 端々吻合，肛門側は端側吻合とした。

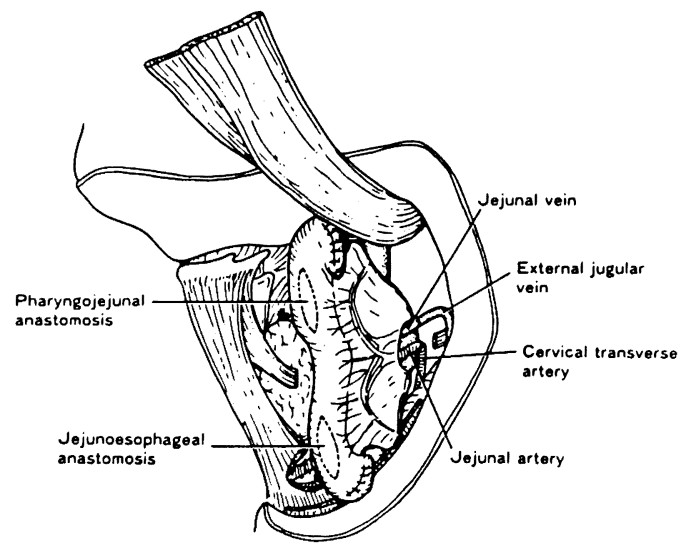

図 9 症例 10

下咽頭頸部食道の痽痕性狭窄に対し, 咽頭と頸胸境 界部食道の間を遊離空腸で bypassした。空腸上下 とも側々吻合とした。 
り，遊離腸管移植に必要な recipient 血管を前 胸壁で容易に得られることがわかった。

症例 9：54歳の女性。9 年前に乳癌の手術 を拒否し, 制癌剤治療を受けていたが, 縦隔り ンパ節転移による胸部食道の狭窄と食道気管支 瘦を発症した。これに対し, 胸壁前食道胃吻合 術（bypass）を予定したが, 胃管が頸部に達し なかったため, 食道と胃管の間に $10 \mathrm{~cm}$ 長の遊 離回腸を間置した。血管吻合には胸肩峰動脈と 撓側皮静脈を用いた。術直後より肺炎から呼吸 不全となり, また術後 7 病日には腹腔内回腸壊 死による腹膜炎をきたし, 回腸切除と再吻合が 行われた。しかし, 病状は改善せず，8病日に は食道回腸吻合部の縫合不全も認められ，16病 日に呼吸不全で術直死となった。

この症例では乳癌胸壁浸潤による拘束性換気 障害, 食道気管支㾇による化膿性気管支肺炎, 緃隔リンパ節転移によるリンパ還流障害に加 え, 回腸壊死・腹膜炎による shock lung の病態 が加わり，呼吸不全を悪化させたものと考えら れる。また，回腸を遊離腸管として採取する場 合, 残った回腸の血行に細心の注意を払うべき ことを知らされた。

症例10：30歳の女性。自殺企図にて塩酸を 嶼下し, 下咽頭頸部食道の痗痕性狭窄を訴えて 来院した。他院で胃切除術がなされていた。瘢 痕性狭窄部をbypassして咽頭と頸胸境界部食 道に $10 \mathrm{~cm}$ 長の遊離空腸を吻合した。血管吻合 には頸横動脈と外頸静脈を用いた(図 9 )。術後 経過は順調で，5週後には全量の食事摄取が可 能になった。

\section{IV．手術成績}

非定型的遊離小腸移植11例中, 在院死亡は 3 例 $27.3 \%$ で，このうち手術合併症による死亡は 1 例のみであり, 他の 2 例は腫崵死であった。 これら 3 例を除き, 退院までの期間は $1 \sim 7$ 力 月, 平均 3 力月, 中央值 2.5 力月であった。

術後合併症は嚥下性肺炎が 4 例 $36.4 \%$ と最も 多く, うち 1 例では喉頭摘出術が追加された。 縫合不全は 2 例 $18.1 \%$ で，1例は吻合部に総量 $70 \mathrm{~Gy}$ の放射線治療が行われた後に発症した。 他の 1 例も長期器械呼吸の症例で, 気道抵抗の 上昇から食道内へ高圧の空気が流入したために
発症した。吻合部狭窄は 2 例 $18.1 \%$ みられた が,いずれも空腸肛門側吻合部の狭窄で, 2 〜 回のブジーで改善した。

血管閉塞による移植空腸の壊死は 1 例 $9.1 \%$ にみられた。壊死腸管を切除したが，その所見 では静脈の閉塞が原因と考えられた。遊離回腸 移植例で, 回腸採取部の口側腸管が $10 \mathrm{~cm}$ にわ たって壊死に陥り, 再手術を余儀なくされた 1 例を経験した。

遊離小腸移植後の食事摂取の状態をみると, 経口攝取開始は術後 $9 \sim 155$ 日, 平均 30 日, 中央 値16日であった。さらに，ほほ全量食事捸取が 可能となり, IVH や経腸栄養が不要になるまで の期間は1.5〜 7.5力月, 平均 3.8 力月, 中央値 3.5 カ月であった。

\section{V. 考察}

遊離腸管移植術の適応は下咽頭頸部食道癌の みならず, 種々の疾患に拡大され, 椂々な応用 法が報告されている ${ }^{6 \sim 9)}$ 。私たちも頸胸境界部食 道癌や食道癌再発例を始め, 表 1 で示したよう な種々の疾患に遊離腸管移植を応用してきた。 将来, この手術の適応はさらに拡がり, 次々と 新しい術式が開発されてゆくものと考えられ る。

従来, 遊離腸管の recipient 血管として, 頸部 の血管が多用されてきた ${ }^{10)}$ 。しかし, 非定型的腸 管移植術では頸部だけでなく, 前胸壁からも recipient 血管を得なければならないことがあ る。Harashina は頸部食道癌術後の咽頭瘻, 前 胸壁胃瘻の二期的再建に胸肩峰動脈と撓側皮静 脈を用いた遊離回腸移植術を報告している1)。

私たちも同様の症例を 3 例経験し，これら血 管が遊離腸管移植に十分使用できることを確認 した。この経験から, 有茎結腸再建例において も, 結腸尖端部の血管をこれら血管に吻合し, 腸管壊死や縫合不全を防止している。胸肩峰動 脈と撓側皮静脈は大胸筋の鎖骨付着部外側 $2 / 3$ を切断することによって容易に見い出すことが でき，根部まで剥離すれば吻合に十分な血管口 径と長さを得ることができる。また，この手技 による術後の機能障害もほとんど認められな い。

前胸壁の血管として, 他に内胸動静脈があ 
る7)。前胸壁中央に近く，血管茎が短くてすむと いう利点がある半面，これら血管を得るために 助軟骨を 2 ～本切除しなければならず, 血管 の口径とくに静脈の口径は撓側皮静脈に比べか なり細いという欠点がある。前胸壁での遊離腸 管移植に頸部の recipient 血管を使用すること もできる。しかし，この方法では長い血管茎す なわち長い腸間膜が必要となり，そのために犠 牲となる腸管の量が多くなる欠点がある。以上 の理由から，私たちは前胸壁での遊離腸管移植 には胸肩峰動脈と撓骨皮静脈を使用している。

再建腸管に何を用いるか,いまだ異論がある。 通常は，空腸上部が用いられる。空腸は血管網 が密であるかわりに腸間膜 (血管茎) が短い。 逆に, 回腸は腸間膜が長くなるが, 血管の数が 少なく, 交通も粗となる傾向がある。また, 私 たちの印象では術後の蠕動による通過障害は空 腸が高度で, 回腸ではより少ない傾向がある。 したがって，短い距離の再建には空腸でもよい が，長い距離の再建には回腸を用いた方がよい と考えている。さらに, 舌の運動障害を伴って いたり，遊離小腸の肛門側腸管が胃管や結腸で あるなど, 術後に嬩下障害や通過障害が予想さ れる症例12)では回腸を用いるようにしている。

一方, 肥満のため腸間膜の血管網がよく確認 できない症例では血管網のより密な空腸を使用 した方が安全である。小腸の他に，回盲部を用 いて気管との間に瘦孔を形成し，発声を可能に する術式(9) S 状結腸を用いる術式2)も報告さ れているが，私たちはその経験がない。結腸の 方が蠕動が弱く, 通過障害が少ないと思われる が, radical neck dissectionが行われた血管の 近くで, 縫合不全を起こしやすい結腸を使用す ることには問題があると考える。

遊離腸管移植では術後の通過障害が問題にな $ろ^{2,13)}$ 。一般的には，腸管の長さと関連があり， 遊離腸管の長さが10〜 $15 \mathrm{~cm}$ 程度なら，できる だけ緊張した状態で吻合するなど注意すればさ ほど問題にならない。しかし，喉頭温存例に遊 離小腸移植が行われた場合, 通過障害が大きな 問題となる。なぜなら，このような症例では術 後嶼下性肺炎を繰り返すことが多く, 場合によ っては喉頭摘出術を余儀なくされることもある からである。さらに，再発例など長期生存が望
めない症例で, 経口摂取を目的として行ったに もかかわらず，それが果たせないという症例も 経験した。したがって，私たちは良性あるいは 根治手術例ではできるだけ喉頭を温存し, 術後 に嚥下訓練を行いながら経口摄取量が増加する のを待つが, 姑息切除や再発など術後生存期間 が短い症例では, 喉頭を切除した方がよいと考 える。

血管閉塞による遊離腸管の壊死は集計によっ

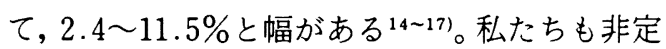
型的遊離小腸移植術の $9.1 \%$ (全小腸移植 23 例中 1 例 $4.3 \%)$ に腸管壊死を経験した。臨床例にお いて，血管の再吻合によって遊離腸管を救うこ とができる安全限界に関する定説はないが, 実 験的に動脈単独あるいは動静脈の同時阻血モデ ルで腸管が回復しうる安全時間は $4 \sim 5$ 時間で あり, 静脈単独の阻血モデルでは 2 時間が安全 限界と報告されている18,19)。その経験以後, 私た ちは血行再建にやや不安のある症例では透明な シリコン・フィルムで空を作製し, 移植腸管の 色調を観察できるようにしている6)。また, 腸管 壊死の症例では外頸静脈を周囲組織からあまり 剝離しないで吻合して閉塞したことから, 外頸 静脈, 撓側皮静脈, 頸横静脈などはできるだけ 根部，すなわち鎖骨下静脈の近くまで剥離し， 圧迫や屈曲による閉塞を防止するように努めて いる。

\section{VI. 結 語}

非定型的遊離小腸移植術11例の経験から, 次 のような結論に達した。

1) 遊離腸管移植術は種々の咽頭食道欠損の再 建に有用であり，また，咽頭から胸骨下緑に至 るいかなる欠損も再建可能である。

2) 頸部の recipient 血管として, 頸横動脈と 外頸静脈が, また, 前胸壁の recipient 血管とし て胸肩峰動脈と撓側皮静脈が有用である。

3) 重要な合併症として, (1) 喉頭温存例におけ る魦下性肺炎, (2) 移植腸管が長いことによる通 過障害, (3) 血管閉塞による腸管壊死, などが認 められたが, 手術適応や術式, 技術の改善によ って克服できるものと考える。 


\section{文献}

1) Seidenberg, B., Rosenak, S.S., Hurwitt, E.S., es al.: Immediate reconstruction of the cervical esophagus by a revascularized isolated jejunal segment. Ann. Surg., 149 : 162-171, 1959.

2 ) Nakayama, K., Yamamoto, K., Tamiya, T., et al. : Experience with free autografts of the bowel with a new venous anastomosis apparatus. Surgery, $55: 796-802,1964$.

3 ) Nakamura, T., Inukuchi, K., and Sugimachi, $\mathrm{K}$.: Use of revascularized jejunum as a free graft for cervical esophagus. Jpn. J. Surg., 5 : 92-102, 1975.

4 ) McKee, D.M., and Peters, C.R. : Reconstruction of the hypopharynx and cervical esophagus with microvascular jejunal transplant. Clin. Plast. Surg., 5:305-312, 1978.

5 ) Flynn, M.B., and Acland, R.D.: Free intestinal autografts for reconstruction following pharyngolaryngoesophagectomy. Surg. Gyncol. Obstet., 149 : 858-862, 1979.

6 ) Hester, T.R., Jr., McConnel, F.M.S., Nahai, F., et al.: Reconstruction of cervical esophagus, hypopharynx and oral cavity using free jejunal transfer. Am. J. Surg., 140 : 487$491,1980$.

7 ) 宮田道夫, 渋沢公行, 平林慎一 - 他 : マイク ロサージャリーを応用した胸部食道の再建. 外 科 MOOK, $51: 93-100,1988$.

8 ）野崎幹弘, 佐々木健司, 平山峻-他：皮成合 併切除を伴なった頸部食道欠損に対する腸管移 植. 外科 MOOK, $51: 79-91,1988$.

9 ）川原英之, 白石武史, 石川広記 - 他：喉頭全摘 後の音声再獲得を目的とした遊離回盲部移植に よる頸部食道再建術。手術，43：1377-1383， 1989.

10）波利井清紀：遊離腸管移植による頸部食道の再 建. 臨外, 38：455-462, 1983.
11) Harashina, T., Kakegawa, T., Imai, T., et al. : Secondary reconstruction of oesophagus with free revascularized ileal transfer. Br. J. Plast. Surg., 34:17-22, 1981.

12）井上要二郎, 藤田博正, 田井良明 - 他：遊離空 腸移植を用いた下咽頭頸部食道再建術後の睘下

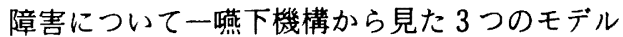
の経験一。形成外科, 32：1037-1042，1989。

13）河野辰幸, 吉野邦英, 滝口 透・他：遊離空腸 移植による下咽頭頸部食道再建術における内压 測定からみた再建食道の運動機能・日気食会報, $37: 354-363,1986$.

14) Gluckman, J.L., McDonough, J.T., McCafferty, G.J., et al. : Complications associated with free jejunal graft reconstruction of the pharyngoesophagus - a multi-institutional experience with 52 cases. Head \& Neck Surg., 7 : 200-205, 1985.

15) Biel, M.A., and Maisel, R.H.: Free jejunal autograft reconstruction of the pharyngoesophagus; review of a 10-year experience. Otolaryngol. Head Neck Surg., $97: 369-375$, 1987.

16) Ferguson, J.L., and Desanto, L.W.: Total pharyngolaryngectomy and cervical esophagectomy with jejunal autotransplant reconstruction; complications and results. Laryngol., $98: 911-914,1988$.

17）上田和毅, 波利井清紀, 山田 敦・他：マイク ロサージャリーによる下咽頭・頸部食道の再 建・日形会誌，9：622-633，1989.

18）矢野健二，秦 維郎，細川 互・他：腸管の経 時的阻血とその変化における実験的研究一腸管 の阻血限界時間とその組織学的変化一. 日形会 誌, $8: 765-773,1988$.

19）矢野健二, 秦 維郎, 松賀一訓・他：腸管の経 時的阻血とその変化における実験的研究 (II) 一動脈と静脈の単独閉塞において一. 日形会誌, 9:495-504, 1989. 